\title{
Bridging the Gap between the World of Learning and Work of Work in the Less Develop Countries of Africa
}

Kingsley Akarowhe*

Department of Educational Foundations, Guidance and Counselling, Faculty of Education, University of Uyo, Uyo, Nigeria

\begin{abstract}
World of learning is an institutionalized arrangement which equip learners to contribute positive to themselves, work place and the society at large before and after graduation, while the world of works is expected to employ and provide an individual monetary capacity to improve on his/her standard of living. In the less developed countries of Africa, there seems to exist a gap between these two worlds, this is shown in the form of inability of graduates to effectively and efficiently performs to what have been inculcated in them in the world of learning. This scenario has raise question by employer of labour in the world of work in doubting the capabilities of the world of learning in producing graduates that would contribute positively to institutionalized setup (private and public/government organization, establishment, and parastatals) and the Africa society at large. Over the years, this have given rise to government of the less developed countries in Africa, international organizations such as UNESCO, USAID and other relevant agencies to work-out modalities to bridge the gap between the two worlds, but solution insight is not often in view. It is against this background that this paper intends to provide solution in bridging the gap between the world of work and work of learning in the less developed countries of Africa.
\end{abstract}

Keywords: Less developed countries; World of learning; World of work; UNESCO; Poverty

\section{Concept of Less Developed Countries}

Development is generically refers to an institutional change which is accompanied by increase in welfare, and fall in cost of living. In other word it is a reduction in unemployment, tribal inequality and poverty for a given nation [1]. It can also be seen as the later stage of growth. Development is term used to describe a nation reduction in its level dependence on aids (financial, monetary, military and administrative) from other countries. According to Umo [2] development is a process by which a high degree of self-reliance economic growth in a given society, sustained over a long time is associated with a substantial reductions in poverty, unemployment and inequality. It is a term commonly associated with the third world countries/less develops countries (LDC).

Development is a term used to appreciate the need for institutional change from the primitive society to a more advance society in the less develop, least develop and even developing countries of the world. The less develop countries in Africa are Angola, Benin, Burkina Faso, Burundi, Cape Verde, Central African Republic, Chad, Comoros, Democratic Republic of Congo, Djibouti, Equatorial Guinea, Equatorial Guinea, Eritrea, Ethiopia, Gambia, Guinea, Guinea-Bissau, Lesotho, Liberia, Madagascar, Malawi, Mali, Mauritania, Mozambique, Niger, Rwanda, Sao Tome and Principe, Senegal, Sierra Leone, Somalia, Sudan, Tanzania, Togo, Uganda and Zambia . Indicators of less developed countries are as follows; low income, low standard of living, low saving, low investment. In other words they revolve in a vicious cycle of poverty.

\section{Concept of World of Learning}

World of learning is an institutionalized arrangement that comprises the activities of the learner(s), teacher(s), government and non-governmental organizations (NGOs). The government and nongovernmental agencies place a prior role of employing the services of the teacher(s) to impact desirable values on an expected learner(s), in which the teacher(s) receive salaries in returns, the learner(s) on their part are expected to use these positive or desirable values to better the society. The world of learning equip learners with saleable skills, deposition, values which will help them to contribute positive to themselves, work place and the society at large before and after graduation for institution of learning [3]

The world of learning in Africa society is expected to inculcate desirable or worthwhile values that will ensure societal development. This is usually achieved through meaningful contribution of the individual learners to societal issues and problems with solution insight in view as shown in Figure 1.

\section{Concept of World of Work}

World of work is a term/concept that can be associated with labour economics. It is an institutionalized arrangement were people engage in meaningful service rendering to an anticipated proportion of consumers with the aim of making ends means. In a more vivid terms, world of work is a agglomeration of individualized jobs which tend to provide financial support to an individual(s), by him/her rendering services to other people. The world of work is aimed at providing employment opportunities for the ever growing population of any country as shown in the Figure 2.

\section{Benefits of the Work of Learning and World of Work in the Less Developed Countries of Africa}

The benefit of the world of learning and world of work in any society are lantern, given the fact they do not only equip the individual sealable

*Corresponding author: Kingsley Akarowhe, Department of Educational Foundations, Guidance and Counselling, Faculty of Education, University of Uyo, Uyo, Nigeria, Tel: +234-08137640978; E-mail: kingsmith1172@gmail.com

Received December 27, 2017; Accepted February 24, 2018; Published March 03, 2018

Citation: Akarowhe K (2018) Bridging the Gap between the World of Learning and Work of Work in the Less Develop Countries of Africa. J Glob Econ 6: 282. doi: $10.4172 / 2375-4389.1000282$

Copyright: (c) 2018 Akarowhe K. This is an open-access article distributed under the terms of the Creative Commons Attribution License, which permits unrestricted use, distribution, and reproduction in any medium, provided the original author and source are credited. 


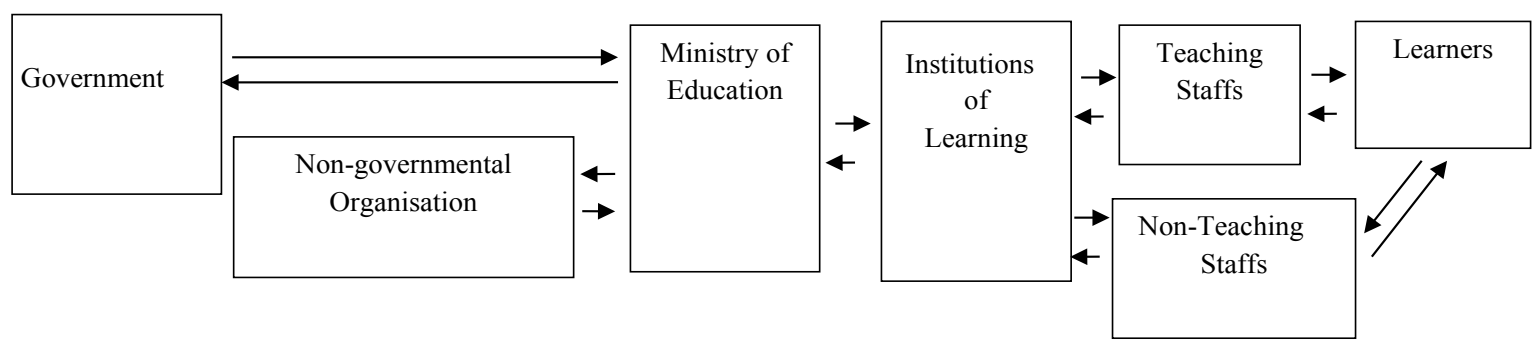

Figure 1: A simple organogram of the working of the world of learning.

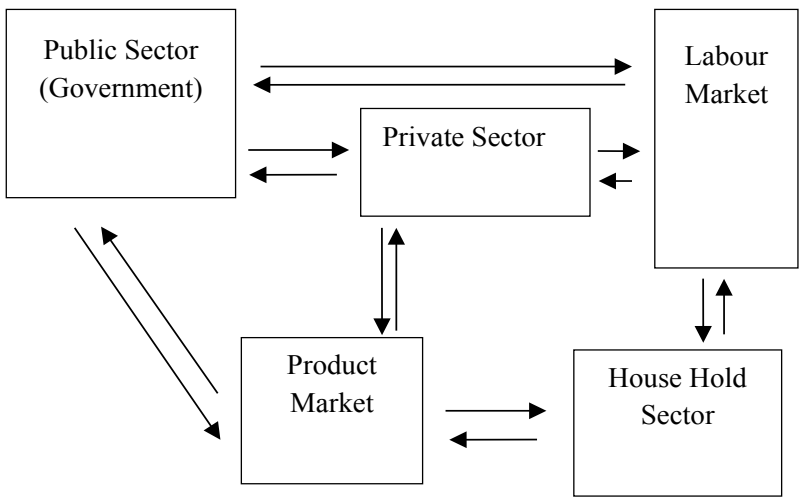

Figure 2: A simple organogram of the working of the world of work.

skills and being gainfully employed; but also help in the development of the society at large, through meaningful contribution from the learners/individuals alike. The following are some of the benefits world of learning and world of work to the less develop countries of Africa [4].

\section{Manpower development}

The world of learning will equip an individual with skills, depositions, worthwhile values that will help him/her in contributing positively to the development of the less developed countries of Africa. This values and dispositions so acquire will in the short-run and longrun affect the individual cognitive, psychomotor and affect domain of educational taxonomy.

\section{Reduction in social vices}

In recent time, the world is facing problem of insecurity. Insecurity is often caused by members of the society involving in social vices such as cultism, robbery, kidnapping and vandalism of properties. Often than not, this is high in the less developed countries of Africa, but due to the effective working of the world of work and world of learning it can be reduced, been that, the world of learning and work places an important role in inculcating the right values desired by the society in the individual to shun social vices, and additionally employment opportunity is provided by the world of work to member of the society.

\section{Self-employment}

In the last decades, the less developing countries of Africa were faced with the problem of citizen over dependent on government for employment opportunities after graduation. Through effective and efficient working of the world of learning an individual in the less developed societies of Africa would be able to set-up small and medium scale enterprises after graduation [5]. An individual being gainful selfemployed is as result of saleable skills he had acquired before graduation in the world of learning.

\section{Income generation}

Through the services to be rendered by an individual in the world of work, he/she receive either wages or salaries, in accordance with trade union demand or individual bargaining power. This in the long-run will help the individual and his family to maintain themselves with the basic needs of life which includes food, clothing, shelter and security.

\section{Acquisition of vocational skills}

The world of learning would help to equip an individual to be able to learn skills for self-reliance in the field of economic, business, accounting, engineering and so forth. This will help one solve issues ranging from technical, administrative, managerial to scientific problems. In the less developed countries of Africa, this will also assist an individual to render helping hands to other individuals.

\section{Consistent skill and knowledge upgrading}

The world of learning is pertinent due to the role it plays in helping individuals in the Africa society to upgrading their skills, in other to counter for the current need in the world of work. This will helps one to contribute meaningfully to any establishment/organizational setup. Since the world of work is dynamic, the world learning continues to strive and ensure that teachers and learners acquired current skills required by employers of labour. This will be attained through consistent skill and knowledge upgrading.

\section{Improved standard of living}

Standard of living is the level or quality of life people in a particular society or country enjoy. Standard of living of any country is not only affected by their level of income but the quality and quantity of goods and services made available to the national of the country. Through the world of learning and world of work the standard of living of people in the less developed countries of Africa can be improved. This due to the fact that, the world of learning will assist an individual to work-out modalities to improve their living condition, while the world of work on the other hand will equip individual(s) with financial capacity to provide for their family, this will both in the short-run and long-run foster improved standard of living.

\section{Increase in social amenities}

In the less developed countries of Africa social amenities can be provided while in other cases increased. This is due to the fact that organization, agencies and non-governmental agencies in the world of work on aprior can partner with the society by providing social amenities where they are located. Social amenities such as pipe borne 
water, housing units, healthcare facilities and educational assistance are often expected to be provided. This in the long-run will helps to eradicate disease infestation, illiteracy and poverty.

\section{The Gaps between Work of Learning and World of Work in the Less Developed Countries of Africa}

In recent years the following are some of the gaps that exist between the world of work and world of learning in the less developed countries of Africa.

\section{Lack of adequate budgetary provision}

In the less developed countries of Africa, government budgetary provision for the world of learning is one major cause of the wide gap between the world of learning and world of work. Lack of adequate budgetary provision have cause many educational institutions to face problem of finance, to acquire the necessary equipments that would assist them in the teaching the learners the needed skills that will help them in the world of work to prosper. This has often makes teaching and learning abstract rather than experimental and learner-based system [6].

\section{Communication lags}

It is an observed fact, that in the less developed countries of Africa, there have not be a good synergy between the world of learning and world of work in term of communicating of vital information that would promote both parties interest. Communication lag is often caused by ideological differential, political affiliation and religious bigotries. These communication barriers in terms of lag have render learner(s)/graduate(s) not fit for the working environment in the world of work.

\section{Lack of proper supervision and monitoring}

In the less developed countries of Africa, when fund are disbursed to educational institution, such fund are not often monitored or supervised to ensure that they are put in proper use. This have often render some project in the world of learning as uncompleted project (elephant project), which in the long-run hinder the learners in terms of acquisition of some needed skills that would assist him/her in the work environment in the world of work after graduation.

\section{Embezzlement, misappropriation and shortage of fund}

Embezzlement, misappropriation and shortage of fund in Africa is not a new term associated with administrative and managerial facet of human endeavour. In recent times, when funds are made available in the world of learning, some individual within the managerial and administrative domain of power and authority often use such fund for their personal ambition, while in some other cases such funds are used for other purposes, thus deviating from a particular preplanned target for a given project or programme to be carried out [7]. The light of the forgoing has lead to shortage of fund in the cause of carrying out a said project or programme in most institutions. Additionally, often than not government tends to release limited funds to the educational institutions in the world of learning, this has hindered the learners over the years from acquiring the needed technical, administrative, managerial, and scientific skills that the fund would have be used to made provision for.

\section{Lack of proper remuneration of producers of labour}

Producer of labour in the less developed countries of Africa are teachers, non-teaching staffs in school, lecturers, non-lecturers in the institution of higher learning. Producers of labour for the world of work are not often paid their salaries or if they are paid the salaries is usually a quota and not full, promotion allowances and other infringe benefits are not given as at when due. This scenario has lead to incessant strikes; work-to-rule and some other time cause ghost-slow, lock-out of most institution of learning in the world of learning in the less develop countries of Africa [8]. Overtime, this has often resulted or triggers a sense of non-commitment of the producers of labour in contributing their quota in other for the learners to acquire what is expected in the world of work.

\section{Corruption and nepotism}

Corruption and nepotism are one of the most pertinent issues in the less develop countries of Africa, which is prevalent in both the world of learning and world of world. Nepotism is often creates lags in the world of learning and world of work given the fact most individual (workers and learners alike), through ethnicity or godfathers are in the institution of learning and work who ought not to be there by merit. This has hinder productivity in the world of learning in terms of learning outcome/performance; and in the world of work in terms of profitability (private sector) or welfare for the citizenry (government/ public sector).

\section{Government policies}

In Africa, especially in the less developed countries, government ideology as expressed in her programmes/policies have often contributed to the gap between the world of learning and world of work, been that they tend to concentrate their interest mostly on the world of learning were individuals are taught skills, dispositions and worthwhile values that are desirable by the state/society, without taking into consideration what such skills and deposition acquire will be used for in the world of work.

\section{Manpower challenges}

Manpower challenges in terms of human incapability, incompetency, inadequacy to man the world of learning and the world of work in recent time, has raised lot of questions that answer ought to be given [9]. These questions arise due to the fact that most graduate are unable to cope with what is needed in the world of work, as a result of lack of prior knowledge and competencies. In the less develop countries of Africa; this has downgraded the educational system.

\section{Unclear curriculum}

Curriculum is defined as a plan of learning experience explicitly or implicitly organizes in school which learners may achieve through learning, some desired skill and values need by the world of work and the society at large. In recent time, the world of learning in the less developed countries of Africa is faced with problem of imparting the needed skills, depositions and worthwhile values that would help learners/graduates contribute greatly their desirable quota needed by employers of labour. Addition to this awkward situation most employers in the world of work have resorted on termination of employment opportunities, reduction in employment opportunities or staffs-in-take, withdrawal of infringe benefits and demotion of employees.

\section{Inability of agencies in both sides to partner together}

Agencies such as the ministries of education and educational institutions in the world of learning are faced with problem of non- 
partnership with organizations and establishment in the world of work. Inability of both parties to partner has in both the short-run and longrun create an isolation or lack mutual understanding between the said parties. This has resulted in most educational institutions in the world of learning not able to know what is needed in the world of work, also for the world of work to contribute to the world of learning in terms of what will be expected of the learners after graduation in the work environment.

\section{Inadequate planning}

The role of planning cannot be overemphasized, giving the fact that learners are not just expected to be taught what curriculum planners felt is needed, but also how they would be able to perform what they have learnt in the world of work properly. The margin gap between these two worlds is often widening due to inadequate planning, both upstream and downstream in the two engulfed world. In the course of planning the curriculum, often than not planners does not take into cognizance what the learners tends to face after graduation in the world of work. Moreover, institution of learning tends to lay more emphases on issuing of certificates and completion of curriculum melt for learners without inculcating the desired skills on learner due to inadequate planning of the curriculum, on the other hand, the world of work fail to place employee in their area of expertise which will helps to promote productivity in the said establishment or organization.

\section{Lack of accurate statistical record}

Statistical data in African are usually falsified, not account for and withheld in both the world of learning and world of work, this may be due to political, ethnic, religious and personal reason so as actualize an expected goal. Lack of accurate statistical record in recent time have not only widened the gap, but also has distorted the information channel need for planning and other statistical discrepancy by researchers.

\section{Bridging the Gaps between Work of Learning and World of Work in the less Developed Countries of Africa}

The gap between the world of learning and world of work can be bridged by looking-inward into some of the associated problem faced in both the learning aspect and work, in light of solution insight as a panacea in the less develop countries of Africa. The following are some of the ways or avenue the gap can be bridged.

\section{Adequate budgetary provision}

Government should ensure sufficient financial provision through her budget and also ensure that such financial provision is disbursed to the world of learning, which will help to bridge the gap between learning and practice in the world of learning. When such budgetary provision are made available, producers of labour would be able to inculcate in the learner the technical-know-how in theoretical and practical terms what he/she will face in the world of work. This is due to provision of adequate teaching and learning facilities [10].

\section{Partnership}

This involves a comprehensive working together of both parties (those in the world of learning and world of work) bearing in mind their area of lags with solution insight in view. This partnership may involves organizing of discussions, seminars, workshops, symposia and field-trips with the objective of eroding the barriers that often impedes graduates in the world of work, in the cause of performing their duties effectively for increase organizational growth. Partnership here could be sub divided into.
Private-public-partnership: This involves a mutual relation between private institutions in the world of

learning collaborating with government agencies. The main aim here is for learners to learn skills and disposition that would assist them be useful in the world of work.

Public-public-partnership: This is an institutionalized arrangement were government institutions of learning engage in a mutual relation with government agencies, ministries and parastatals in the world of work with the view of providing solution insight into problems affecting the two parties, bearing in mind the interest of the learners, so as for them to be fit for the world of work.

Private-private-partnership: This is an institutionalized cooperation, in which private institution of learning and private agencies or non-governmental organization, engage in meaning outfit which tends to propel learners to be able to perform as expected in the world of work, the skills, values and technical know-how they have acquired in the world of learning.

\section{Restructuring learning institution curriculum}

Curriculum planners in the less develop countries of Africa, should endeavour to restructure what the learners are expected to learn, in other for them to effectively utilize what they have learnt in the world of work after graduation. This will go a long way to improve the learners' capability in delivery effectively what is needed in the world of work even while in institution of learning. Learners should not only be taught dogmatic beliefs implemented in the curriculum, but should learn what will propel them to be effective and efficient in the world of work. The light of this will help learners to contribute positive to themselves and the Africa society in the long-run.

\section{Planning}

Planning involves benchmarking by the ministries of education and other agencies in the world of learning. This is done through considering the needs and expectations of the world of work. Planning involves a deliberate chatting of the remote problem facing the world of learning, by stakeholders in the world of learning with success factor in view the process [11]. Additionally, it involves teams work and decisive memorandum between the world of learning and the world of work. Planning will in the long-run helps to overcome some challenges that are likely to be faced by learners in the world of work.

\section{Integration}

Integration is the process in which stakeholder such as teachers, lecturers and others agents in the world of learning, take a deliberate step to inculcate on the learners what would be needed in the world of work. Integration may involve a series of collaboration between the world of learning and the world of work, such collaboration may involve organizing workshops and seminars for learners. Integration may be done through re-orientation of the learners, restructuring the mode of teaching and learning or even introduction of relevant courses that will helps the learners to effective and efficient, in the discharge of his/her duties in the world of work before/after graduation.

\section{Student internship programme}

Internship programme is an avenue students are expose to the world of work even while in institution of learning, this is done through these institution of learning introducing a general course for the students, in which students are expected to practically work in some private establishment(s)/organization(s) for a month(s), at the 
end, these organization(s) are expected to score the student in term of performance which will form their examination score while the institution of learning assess their work booklet and give a general test as part of their continuous assessment. This in the long-run will in still in the students/learners need to be serious with their study and by so during get use to the world of work [12].

\section{On-the-job-training}

In the world of work, employer of labour should endeavour to workout modalities by giving on-the-job-training to employee. This will in the both the short-run and long-run help the employee to upgrade their know-how and skills, so as to carry out their job efficiently and effectively in the world of work.

\section{Proper remuneration of producers of labour}

In the world of learning, the producers of labour such as lecturers, teachers and other agents/staffs should be given their remuneration benefits as at when due. This will go a long way to boost their morale while they discharge their duties, also this will assist them to explore the necessary avenues that would makes the learners more productivity in the world of work after graduation [13].

\section{Recommendations}

1. The United State Agency for International Development (USAID), African Union (AU), Economic Community of West African States (ECOWAS), East African Community (EAC) and United Nation (UN) through the United Nation Educational, Scientific and Cultural Organization (UNESCO) and other global agencies should provide assistance to the institutions of learning in the less developed countries of Africa in the form of finance and other prior materials. This will help to bridge the gaps in teaching/learning process in the world of learning and raise the standard of job performance in the world of work by graduates and undergraduates.

2. United Nation Educational, Scientific and Cultural Organization (UNESCO) should partner with educational institutions in the less development countries through organizing of seminars, workshops, symposia and discussion for both parties, which will help to erode the gaps in the two worlds.

3. There should be strong collaboration between the two institutions that is world of learning and world of work. This will ensure that both parties provide meaningful contribution to each other that would help to propel the learners after graduation to discharge their jobs efficiently and effectively in the world of work.
4. Government of the less developed countries of Africa should provide formidable policies that would help the world of work contribute its' quota to the world of learning vice-visa.

\section{Conclusion}

The world of learning tends to equip individuals (learners) with skills, values and technical know-how that will help an individual face the ever changing world of work, while the world of work tends to equip the individual with monetary and psychological gain which will on aprior in the long-run contribute to development of the less developed countries of Africa. If practical steps as pinpoint by the researcher are taking into consideration, it will go a long-way to help the less develop countries of Africa in terms of development which encompasses both worlds and thus contributing meaningfully to the Africa society at large.

\section{References}

1. Akarowhe K (2017) Benchmarks for Business Administration for Sustainable National Development. Arabian Journal of Business and Management Review 7: $1-3$

2. Umo JU (1986) An Africa Perspective. John West Publication Ltd.

3. https://en.wikipedia.org/wiki/Least_Developed\%20\%20_Countries.

4. Jickling B, Arjen EW (2008) Globalization and environmental education Looking beyond sustainable development. Journal of Curriculum Studies 40 $1-21$.

5. Clayton S, Myers G (2015) Conservation psychology: Understanding and promoting human care for nature. John Wiley \& Sons.

6. Vob JP, Smith A, Grin J (2009) Designing long-term policy: rethinking transition management. Policy Sciences 42: 275-302.

7. Pahl Wostl C, Mostert E, Tàbara D (2008) The growing importance of social learning in water resources management and sustainability science. Ecology and Society 13: 1-24.

8. Kopnina H (2012) Education for sustainable development (ESD): the turn away from environment in environmental education? Environmental Education Research 18: 699-717.

9. Wals AE (2014) Sustainability in higher education in the context of the UN DESD: a review of learning and institutionalization processes. Journal of Cleaner Production 62: 8-15.

10. Cundill G, Rodela R (2012) A review of assertions about the processes and outcomes of social learning in natural resource management. Journal of Environmental Management 113: 7-14.

11. Van den Bosch S (2010) Transition experiments: exploring societal changes towards sustainability.

12. Keen M, Brown VA, Dyball $R$ (2005) Social learning in environmental management: towards a sustainable future. Routledge.

13. Muro M, Jeffrey $P$ (2008) A critical review of the theory and application of social learning in participatory natural resource management processes. Journal of Environmental Planning and Management 51: 325-344. 